\title{
Enteropathogenic Escherichia coli-A Summary of the Literature
}

\author{
Anca Delia Mare, Cristina Nicoleta Ciurea (1), Adrian Man*(D), Bianca Tudor, Valeriu Moldovan, Luminița Decean \\ and Felicia Toma
}

check for updates

Citation: Mare, A.D.; Ciurea, C.N.; Man, A.; Tudor, B.; Moldovan, V.; Decean, L.; Toma, F. Enteropathogenic Escherichia coli-A Summary of the Literature. Gastroenterol. Insights 2021, 12, 28-40. https://doi.org/10.3390/gastroent 12010004

Academic Editor: Chien-Feng Li

Received: 27 December 2020

Accepted: 25 January 2021

Published: 27 January 2021

Publisher's Note: MDPI stays neutral with regard to jurisdictional claims in published maps and institutional affiliations.

Copyright: (c) 2021 by the authors. Licensee MDPI, Basel, Switzerland. This article is an open access article distributed under the terms and conditions of the Creative Commons Attribution (CC BY) license (https:/ / creativecommons.org/licenses/by/ $4.0 /)$.
Department of Microbiology, George Emil Palade University of Medicine, Pharmacy, Science and Technology, 540139 Târgu Mureș, Romania; anca.mare@umfst.ro (A.D.M.); cristina.ciurea@umfst.ro (C.N.C.); bianca.tudor@umfst.ro (B.T.); valeriu.moldovan@umfst.ro (V.M.); luminita.decean@umfst.ro (L.D.); felicia.toma@umfst.ro (F.T.)

* Correspondence: adrian.man@umfst.ro

\begin{abstract}
Diarrheal disease is still a major public health concern, as it is still considered an important cause of death in children under five years of age. A few decades ago, the detection of enteropathogenic $E$. coli was made by detecting the $\mathrm{O}, \mathrm{H}$, and $\mathrm{K}$ antigens, mostly by agglutination. The recent protocols recommend the molecular methods for diagnosing EPEC, as they can distinguish between typical and atypical EPEC by identifying the presence/absence of specific virulence factors. EPEC are defined as diarrheagenic strains of $E$. coli that can produce attaching and effacing lesions on the intestinal epithelium while being incapable of producing Shiga toxins and heat-labile or heat-stable enterotoxins. The ability of these strains to produce attaching and effacing lesions enable them to cause localized lesions by attaching tightly to the surface of the intestinal epithelial cells, disrupting the surfaces of the cells, thus leading to the effacement of the microvilli. EPEC are classified on typical and atypical isolates, based on the presence or absence of $E$. coli adherence factor plasmids. All the EPEC strains are eae positive; typical EPEC strains are eae+, bfpA+, while atypical strains are eae+, $b f p \mathrm{~A}-$. No vaccines are currently available to prevent EPEC infections.
\end{abstract}

Keywords: diarrheal disease; typical/atypical enteropathogenic E. coli; virulence factors; diagnostic

\section{Introduction}

Diarrheal disease is still a major health problem, and it is considered an important cause of morbidity and mortality, especially in infants and children under five years old. Although the disease primarily affects populations from developing countries, where sanitation, water supplies, and the medical addressability rate are inadequate, there are still reported cases in developed countries [1-4]. The etiology of the infectious diarrheal disease is influenced by the geographic area. Viruses (such as rotavirus, adenovirus, norovirus) are the most frequent etiological agents worldwide. Infections with Campylobacter spp. and Salmonella spp. are frequently reported in the developed countries, while diarrheagenic strains of E. coli, Vibrio spp. are encountered mostly in developing countries [5-7].

In 1885, Theodor Escherich, a German pediatrician described, for the first time, Bacterium coli commune, as a commensal Gram-negative rod from the healthy individual's intestinal flora. These rods were afterward renamed Escherichia coli (E. coli), in his honor. Only after a few decades, in 1935, they were considered pathogens, being associated with an outbreak of "cholera infantum", a severe gastroenteritis affecting neonates [8,9]. From that moment, a remarkable number of studies were conducted, describing E. coli from numerous points of view (serological, antibiotic resistance, molecular, genetic engineering, sequencing, etc.), leading to the fact that, in our days, it is considered as one of the best-characterized bacteria. Even so, there are still many unknowns about this pathogen, which, even nowadays, is responsible for a large number of infections in healthy or immunocompromised persons (diarrhea, pneumonia, urinary, wounds infections, sepsis, meningitidis) $[10,11]$. 
E. coli is a versatile microorganism, and even if the invasive infections are those that are more likely to evolve with life threatening complications, the diarrheagenic strains of E. coli are still important pathogens, especially in the pediatric departments. Among these strains, Enteropathogenic E. coli (EPEC) is a particularly important one, as it is a bacterial etiological agent in a pathology that is dominated by viruses, making it easy to be "forgotten" or not taken into consideration, especially in the case of infantile diarrhea. The fact that these strains present multiple phenotypic differences, that they possess different, multiple virulence factors (some of them belonging to other pathotypes), and that they are still evolving, makes them a group of bacteria that will always be of interest for physicians from different medical departments. The main objective of this review was to summarize the most important, relevant, and up to date information available in the literature about this reemerging pathogen, and to provide an overview of the most important characteristics of EPEC strains.

The diarrheagenic strains of $E$. coli are a very homogeneous group of intestinal pathogens, with different characteristics regarding the antigen structure, virulence mechanisms, host colonization sites, and clinical evolution [11]. The $\mathrm{O}$ (lipopolysaccharide) and $\mathrm{H}$ (flagellar) antigens are used for the serological classification of the pathogenic strain of E. coli. Because of the high diversity of these antigens ( $187 \mathrm{O}$ antigens, $53 \mathrm{H}$ antigens), currently, serotyping is considered a laborious, costly, and unreliable diagnostic tool due to the cross-reactivity between different serogroups $[12,13]$. Most of the recent diagnostic protocols recommend the classification/identification of diarrheagenic E. coli using molecular methods, which can identify the virulence factors of these strains. Based on the presence/absence of virulence factors, the diarrheagenic strains of E. coli are classified into 6 major pathotypes and a hybrid one (Table 1). The horizontal gene transfer between different strains is an important mechanism that leads to the diversity of these strains, keeping them in a constant movement between the classically described pathotypes. Some strains that combine virulence factors from different pathotypes are considered hybrids, and they can be potentially more virulent than the original strains $[6,11,14]$. Plasmids, bacteriophages, transposons, pathogenicity islands, insertion sequences (mobile genetic elements-MGEs) plays important roles in the genomic plasticity of E. coli [15]. Whole genome sequencing is considered the gold standard technique which can accurately serotype strains and evaluate relatedness among isolates based on differences in gene content or allelic variation [16-19]. This technique revealed that E. coli presents a conserved core of genes (common to pathogenic and commensal strains as well) that acquired, by horizontal gene transfer, small cluster of genes and genomic islands associated with virulence [20].

Table 1. Pathotypes of Diarrheagenic E. coli.

\begin{tabular}{|c|c|c|c|c|c|c|}
\hline $\begin{array}{c}\text { Pathotype of } \\
\text { Diarrheagenic E. coli }\end{array}$ & Acronym & Virulence Factors & $\begin{array}{c}\text { Diagnostic } \\
\text { Targets for PCR }\end{array}$ & Disease & $\begin{array}{l}\text { Clinical } \\
\text { Symptoms }\end{array}$ & Ref \\
\hline $\begin{array}{c}\text { Enteropathogenic } \\
\text { E. coli }\end{array}$ & EPEC & $\begin{array}{l}\text { Locus of enterocyte } \\
\text { effacement (LEE), } \\
\text { intimin, } \\
\text { bundle-forming pilus }\end{array}$ & bae, bfp $A$ & $\begin{array}{l}\text { Acute/persistent } \\
\text { diarrhea in } \\
\text { children }\end{array}$ & $\begin{array}{l}\text { Watery diarrhea, } \\
\text { vomiting }\end{array}$ & {$[6,17,21]$} \\
\hline $\begin{array}{c}\text { Enterohaemorrhagic } \\
\text { E. coli } \\
\text { (Shiga } \\
\text { toxin-producing) }\end{array}$ & EHEC/STEC & $\begin{array}{l}\text { Shiga toxin } 1 \text { and / or } 2 \\
\text { LEE, adhesins (EHEC) }\end{array}$ & $\begin{array}{l}\text { stx1, stx2, eae } \\
\text { ehxA, bfp }\end{array}$ & $\begin{array}{c}\text { Hemolytic- } \\
\text { uremic syndrome, } \\
\text { hemorrhagic } \\
\text { colitis }\end{array}$ & Bloody diarrhea & {$[6,11,17]$} \\
\hline $\begin{array}{l}\text { Enteroinvasive } \\
\text { E. coli }\end{array}$ & EIEC & $\begin{array}{l}\text { Shiga toxin, hemolysin, } \\
\text { cellular invasion, Ipa }\end{array}$ & $\begin{array}{l}\text { ipaH, other ipa } \\
\text { genes }\end{array}$ & $\begin{array}{l}\text { Shigellosis-like } \\
\text { syndrome }\end{array}$ & $\begin{array}{l}\text { Watery, bloody } \\
\text { diarrhea }\end{array}$ & {$[6,11]$} \\
\hline $\begin{array}{c}\text { Adherent Invasive } \\
\text { E. coli }\end{array}$ & AIEC & $\begin{array}{l}\text { Type } 1 \text { fimbriae, } \\
\text { cellular invasion }\end{array}$ & none & $\begin{array}{l}\text { Associated with } \\
\text { Crohn disease }\end{array}$ & $\begin{array}{c}\text { Persistent } \\
\text { intestinal } \\
\text { inflammation }\end{array}$ & {$[12,17,22]$} \\
\hline $\begin{array}{l}\text { Enterotoxigenic } \\
\text { E. coli }\end{array}$ & ETEC & $\begin{array}{c}\text { Heat-labile and } \\
\text { heat-stable toxins, } \\
\text { CFAs (colonization } \\
\text { factors) }\end{array}$ & elt, est & $\begin{array}{l}\text { Traveler's } \\
\text { diarrhea }\end{array}$ & $\begin{array}{l}\text { Watery diarrhea, } \\
\text { vomiting }\end{array}$ & {$[6,11,17]$} \\
\hline
\end{tabular}


Table 1. Cont

\begin{tabular}{|c|c|c|c|c|c|c|}
\hline $\begin{array}{c}\text { Pathotype of } \\
\text { Diarrheagenic } E \text {. coli }\end{array}$ & Acronym & Virulence Factors & $\begin{array}{c}\text { Diagnostic } \\
\text { Targets for PCR }\end{array}$ & Disease & $\begin{array}{c}\text { Clinical } \\
\text { Symptoms }\end{array}$ & Ref \\
\hline $\begin{array}{l}\text { Diffusely Adherent } \\
\text { E. coli }\end{array}$ & DAEC & Adhesins & Afa/Dr adhesins & $\begin{array}{l}\text { Diarrhea in } \\
\text { children }\end{array}$ & Watery diarrhea & {$[6,17,23]$} \\
\hline $\begin{array}{c}\text { Enteroaggregative } \\
\text { E. coli } \\
\text { (hybrid pathotype) }\end{array}$ & EAEC & $\begin{array}{l}\text { Adhesins, toxins and } \\
\text { secreted proteins }\end{array}$ & $p A A, A g g R, A A F s$ & $\begin{array}{l}\text { Diarrhea in } \\
\text { children }\end{array}$ & $\begin{array}{c}\text { Vomiting } \\
\text { diarrhea (with } \\
\text { mucus) }\end{array}$ & {$[6,11]$} \\
\hline
\end{tabular}

\section{EPEC Definition and Classification}

EPEC was the first identified pathotype of diarrheagenic E. coli, being the causative agent of a few outbreaks of infantile diarrhea in 1940-1950 [24]. Until a few decades ago, the $\mathrm{O}$ (somatic), $\mathrm{H}$ (flagellar), and $\mathrm{K}$ (capsular) antigens were the basis for the classification of EPEC strains. In 1987, when World Health Organization recommended that O26, O55, O86, O111, O114, O119, O125, O126, O127, O128, O142, and O158 should be considered as EPEC serogroups, some studies already reported that some of these serogroups included strains from other serotypes [14,25]. Serogroups such as O39, O88, O103, O145, O157, and O158 are now considered to be included in EPEC pathotype [26]. Among EPEC isolates, $\mathrm{H} 2$ and $\mathrm{H} 6$ are the most common flagellar antigens associated, but there are also some less common $\mathrm{H}$ types (such as H7, H8, H9, H12, H21, H27, H25, and H34), and some EPEC strains are classified as H negative (non-motile) $[11,14,24,25,27]$. Because of the high diversity of these antigens, serotyping is no longer considered a rapid diagnostic tool, nor a reliable one $[13,28,29]$.

In 1982, EPEC was defined as "diarrheagenic E. coli belonging to serogroups epidemiologically incriminated as pathogens but whose pathogenic mechanisms have not been proven to be related either to heat-labile enterotoxins or heat-stable enterotoxins or to Shigella-like invasiveness" [30]. Now, EPEC strains are defined, based on their virulence factors, as diarrheagenic strains of $E$. coli that can produce attaching and effacing (A/E) lesions on the intestinal epithelium, but unable to produce Shiga toxins and heat-labile (LT) or heat-stable (ST) enterotoxins [3,11,24].

The most important characteristic of EPEC is the ability to produce A/E lesions, which enable them to cause localized lesions by attaching tightly to the surface of the intestinal epithelial cells, disrupting the cell surfaces, finally leading to the effacement of the microvilli. Intimin is an outer membrane protein, encoded by the eae gene, which mediates the intestinal cell attachment. The attachment is facilitated by Tir (Translocated intimin receptor), an effector inserted in the host plasma membrane, where it functions as a receptor for intimin. By a type-three-secretion-system (T3SS), EPEC can inject a large number (at least twenty-five) effector proteins in the host cells. All the required genetic elements for the A/E lesion are encoded on the locus of enterocyte effacement (LEE), a large genomic pathogenicity island [31-34].

EPEC can also be classified on typical and atypical isolates, based on the presence or absence of EAF (plasmid E. coli adherence factor), where $b f p$ and per, two important operons, are localized. bfp encodes the type IV bundle-forming pilus (BFP), while per encodes the plasmid-encoded regulator (Per), a transcriptional activator [31]. All the EPEC strains are eae positive (+), so typical EPEC are described as eae+, bfpA+, while atypical strains are considered those eae+, bfpA- (negative) [11,27,31,35]. Some of the atypical EPEC strains might possess other virulence factors such as enteroaggregative heat-stable toxin (EAST1), hemolysin, not encoded on LEE [26].

\section{Virulence Factors}

EPEC can adhere, at least in vitro, to cell lines and organ cultures in a three-dimensional microcolonies pattern, named localized adherence (LA) pattern. BFP mediates LA phenotype, and it is also involved in antigenicity, biofilm formation, and autoaggregation [11]. EPEC are non-invasive pathogens that can induce lesions by introducing effector proteins 
directly into the host cells, using a type-three-secretion-system (T3SS). These effectors are encoded on the LEE pathogenicity island. LEE contains genes that encode T3SS (Esc, Sep), the outer membrane adhesin (intimin, essential for the adherence on the host cells, encoded by eae gene), translocators (EspA/B/D), effector proteins (EspF/G/H, Map, EspZ), chaperones (Ces proteins), the translocated intimin receptor (Tir), and regulatory proteins such as LEE-encoded regulator (Ler), a global regulator of LEE proteins (GrlA-activator, GrlR-repressor) [11,36-40].

Various non-LEE (Nle) encodes effector genes (cif, espI/nleA, nleB, nleC, nleD, nleE, nleH), located outside of the LEE region, clustered in six pathogenicity islands. The Nle proteins can increase the bacterial virulence by preventing/modulating the host inflammatory response and by disrupting the tight junctions and the cytoskeleton of the host cells $[11,31,33,36]$. Along with Nle A, EspF, and Map, other non-LEE encoded effector proteins are involved in the disassembly of the tight junctions [41]

In addition to BFP, some EPEC strains may present other fimbriae or pili (type 1 fimbriae, E. coli common pilus), flagella, ast A gene (encoding EAST1-the enteroaggregative E. coli heat-stable enterotoxin 1), autotransporter proteins (EspC), or produce a hybrid adherence phenotype in HeLa cells (LA and aggregative-like pattern), but their involvement in the pathogenicity still needs to be studied $[11,42]$.

\section{Pathogenesis}

Attaching-and-effacing was described by Nataro and Kaper, in 1998, as the "hallmark" of the EPEC infections, a lesion that is characterized by the intimate attachment of the bacteria to the host epithelial cell membrane and the effacement of the microvilli [25]. Since then, a lot of studies have focused on describing this main pathogenic mechanism, which is common to the typical and atypical EPEC strains. The interaction between EPEC and the host cells is described as a four-stage process (Figure 1).

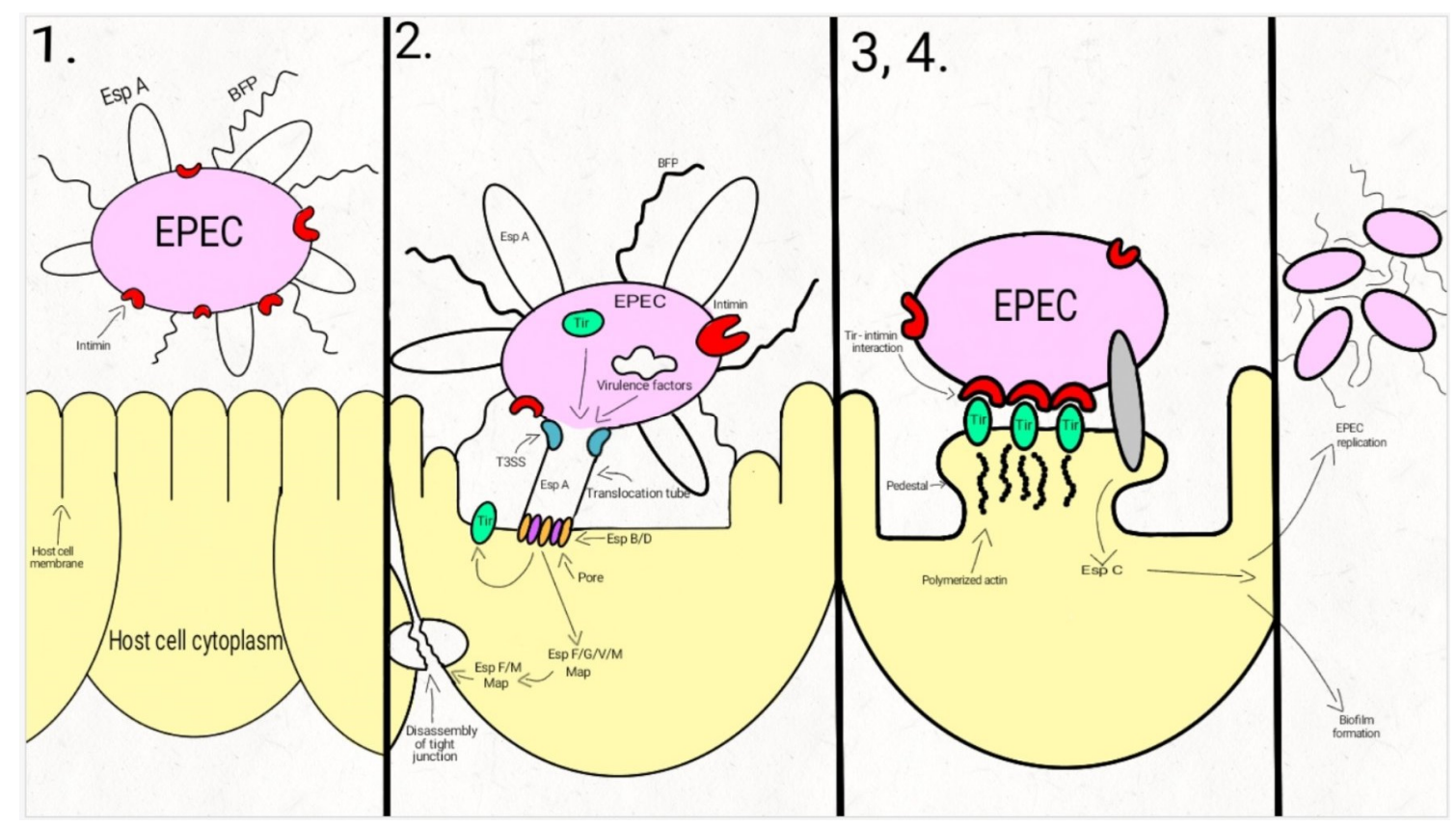

Figure 1. Schematic representation of the EPEC adherence mechanism: 1. EPEC express Bfp and EspA; 2. After attaching to the enterocyte (trough Bfp), EPEC use a T3SS to infect many effectors in the cell. The phosphorylated Tir is inserted into the host cell membrane; 3 . The bacterial intimin binds to the modified Tir, attaching the bacteria to the host cell. Actin and cytoskeletal elements are accumulated near the site of the bacterial adherence. EspC is inserted into the cell trough an autotransporter system, T5SS. 4. The cytoskeletal elements, accumulated near the site of the attachment, leads to the formation of the pedestal structure, characteristic for EPEC. In the first step, EPEC cells express the intimate adhesin intimin, Bfp (bundle-forming pili), and EspA (short filaments surface-associated). Environmental factors regulate the expression of these virulence factors, influencing the site of the bacterial colonization (small/large bowel) [43-45]. 
In the second step, EPEC strains adhere to the intestinal epithelium through Bfp and EspA, forming dense microcolonies on the cell's surface, in a pattern described as localized adherence. The type-three-secretion-system creates a pore, enabling the bacteria to inject Tir and a large number (at least 25, up to 50) of effector molecules into the host cell. These effectors facilitate bacterial colonization, immune evasion, and regulate inflammatory response and host cell death. They also activate the host cell-signaling pathways, causing the alteration of the cytoskeleton, leading to the loss of the microvilli. After tyrosine-protein kinase and protein kinase A modifies Tir, it is inserted into the host cell membrane [43,44,46-54].

Enterocyte effacement and intimate bacterial attachment to the host cell characterizes the third step of EPEC infection. The bacterial cells lose the EspA filaments from their surface. The bacterial intimin (encoded by eae) binds to the modified Tir, causing the intimate attachment of the bacteria to the host cell. In this phase, actin and cytoskeletal elements are accumulated near the site of the bacterial adherence $[43,44,55]$. An autotransporter system, T5SS (type V secretion system), mediates the secretion of EspC, [42,56-58], a protein involved not only in epithelial cell cytotoxicity, but also in bacterial replication and biofilm formation [56,59-61].

During the fourth step, the cytoskeletal elements, accumulated near the site of the attachment, leads to the formation of the pedestal structure, characteristic for EPEC. The effector molecules (translocated from the bacteria) disrupt the cell processes, leading, eventually, to cell death $[24,43,62]$.

The clinical symptoms of EPEC diarrheal disease occurs before the complete establishment of the A/E lesions and the loss of the microvilli, so these mechanisms are most likely involved in the exacerbation of the diarrhea. The rapid onset of the diarrhea (sometimes only after a few hours after the ingestion) is more likely to be the result of a secretory mechanism [63,64].

EPEC can imbalance the host cells electrolyte transport, and by the dysregulation of these transport pathways, it is responsible for the rapid onset of the symptoms. $\mathrm{Na}+\mathrm{H}+$ (NHE2-3), $\mathrm{Na}+$ /glucose (SGLT-1), and $\mathrm{Cl}-/ \mathrm{HCO}-$ (DRA/PAT1) exchangers are responsible for the water and solutes intestinal absorption. CFTR (the apical cAMP-dependent cystic fibrosis transmembrane conductance regulator) is responsible, among other factors, for the osmotic gradient which controls the movement of water into the intestinal lumen. EPEC establish a disequilibrium in the $\mathrm{Na}+\mathrm{Cl}-$ electroneutral exchange through the plasma membrane, reducing water absorption. Moreover, by modulating the AQP (epithelial aquaporin) expression, the water transport is directly altered by EPEC [63,65-68].

EPEC is capable of disrupting the epithelial barrier function and structure. By activating MLC kinase, EspB-mediated phosphorylation, activation of PKC $\alpha$, EPEC can increase the paracellular permeability. EPEC is also responsible for the disruption of epithelial apical junctional complexes and the alteration of the tight junctional proteins [63].

The inflammatory response is considered more likely to be involved in the severity and the duration of the disease than in the early stages of the infection. An increase of IL-1 $\beta$, $\mathrm{TNF} \alpha$, interferon (IFN) $\gamma$ in the infected mucosa is associated with the EPEC infection. Both pro-inflammatory and anti-inflammatory pathways of the epithelial cells are involved in the EPEC mediated inflammatory response. The EPEC secreted components are responsible for the pro-inflammatory response, while the effectors inserted in the host cells by the T3SS attenuates the inflammatory response $[49,63,69]$.

\section{Clinical Aspects}

EPEC causes acute or persistent diarrhea, especially in young children under two years old. Typically, EPEC causes acute watery diarrhea, associated with fever, vomiting, and dehydration. The onset of the disease is rapid, with symptoms appearing after a few hours after the ingestion of bacteria $[44,46]$. EPEC infections are more likely to evolve as acute ones, but persistent cases lasting more than two weeks with associated complications such as dehydration and malnutrition are also reported. Compared to other infectious diarrheal agents, (rotavirus, adenovirus, Salmonella spp., Campylobacter 
spp.), EPEC infections are more likely to evolve as persistent diarrhea, and patients often require hospitalization [24,70,71]. Intolerance to cow's milk and failure to respond to oral rehydration therapy were also associated with EPEC infections [31,49].

The clinical characteristics of infectious diarrhea caused by EPEC are difficult to be clearly stated, as most of the times, if EPEC is detected in a clinical specimen, it is considered the etiological agent, without ruling out the possibility of mixed infections $[31,72,73]$. Studies published in the last years showed that EPEC was the most frequent pathogen detected in mixed intestinal infections [74,75].

Recently, the presence of EPEC was detected from asymptomatic carriers [74,76]. There are three proposed explanations for this asymptomatic state: The host susceptibility, the presence of the secretory immunoglobulin A (sIgA), and the variability of the diagnostic tests [26].

Diagnostic

In microbiology laboratories, the traditional diagnostic of EPEC is still conducted for children under two years old, with infectious diarrhea, as part of the routine. The protocols involve screening from E. coli colonies, obtained from primary isolation, by slide agglutination with antisera against the classical EPEC serogroups. This method is easy to perform, available in most laboratories, but presents a few important disadvantages: It is unable to distinguish typical/atypical EPEC, cross-reactions can occur because of the high diversity of the serogroups, and false-negative reactions are frequent because some EPEC strains belong to other serogroups than the classic ones.

The recent protocols recommend the molecular methods (PCR-Polymerase Chain Reaction) for EPEC diagnostic, which, based on the presence/absence of specific virulence factors, can distinguish between typical and atypical EPEC (Table 2).

Table 2. Virulence genes detected with Polymerase Chain Reaction (PCR) to distinguish between typical/atypical EPEC.

\begin{tabular}{cccc}
\hline EPEC Strain & eae & $b f p$ & stx \\
\hline Typical EPEC & + & + & - \\
\hline Atypical EPEC & + & - & - \\
\hline
\end{tabular}

There are a lot of modern possibilities for the identification of the EPEC strains, based on their virulence factors (proteins, intimin, BFP, and T3SS can be considered as targets for diagnosis), and methods based on cell cultures are laborious and not available in most laboratories [11,77]. Immunoblotting, immunofluorescence methods using polyclonal or monoclonal antibodies against BFP [78,79], rapid tests, detecting EspB, and a secreted protein, are also described (immunochromatographic tests [80], latex-agglutination from culture supernatant [81], agglutination test using latex beads coated with anti-EspB monoclonal antibodies [82]).

Treatment

Most of the actual protocols for the management of infectious diarrhea are recommend only symptomatic treatments (rehydration, probiotics, antimotility agents, probiotics). EPEC infections are usually self-limiting, so antibiotics may be necessary only in the rare cases of persistent diarrhea or other complications [83-86].

Antibiotic Resistance

Antibiotic resistance is a recognized global phenomenon for E. coli, as well as for the EPEC strains, with different prevalence around the world, because of the different antibiotic control/prescribing/reporting protocols, as well as because of the mobile genetic elements $[6,15,84,87]$. The geographic area, the social status of the region, the period of the study, and the laboratory protocols that are used for the evaluation of the antibiotic susceptibility are major factors that influence the incidence of the reported antibiotic resistance. EPEC strains can present resistance against many antibiotics, including penicillins, cephalosporins, trimethoprim-sulfamethoxazole, fluoroquinolone, and aminoglycosides, and the antibiotic resistance is more prevalent in moderate and week biofilm-producing 
strains (Table 3) $[24,88,89]$. A Brazilian study reported higher rates of antibiotic resistance among typical EPEC strains than among the atypical ones [90]. A major concern nowadays is the emergence of multidrug-resistant strains, which are frequently reported around the globe $[11,90,91]$.

Table 3. Resistance Profiles of EPEC Strains Isolated from Humans.

\begin{tabular}{|c|c|c|c|c|c|c|c|c|c|c|c|c|}
\hline \multirow{2}{*}{$\begin{array}{l}\text { EPEC Strain } \\
\text { Reference }\end{array}$} & \multicolumn{9}{|c|}{ EPEC } & \multicolumn{3}{|c|}{ Atypical EPEC } \\
\hline & $\begin{array}{c}\text { Southeastern } \\
\text { China, 2014 } \\
\text { [92] }\end{array}$ & $\begin{array}{c}\text { Southwest } \\
\text { China, } \\
2018 \text { [93] }\end{array}$ & $\begin{array}{c}\text { Western } \\
\text { Iran, } \\
2013 \text { [94] }\end{array}$ & $\begin{array}{l}\text { Iran, } \\
2020 \\
{[95]}\end{array}$ & $\begin{array}{l}\text { India, } \\
2018 \\
{[96]}\end{array}$ & $\begin{array}{l}\text { Qatar, } \\
2020 \\
{[97]}\end{array}$ & $\begin{array}{l}\text { Tanzania, } \\
2016[98]\end{array}$ & $\begin{array}{l}\text { Northwest } \\
\text { Mexico, } \\
2016 \text { [99] }\end{array}$ & $\begin{array}{c}\text { Romania, } \\
2020 \\
{[100]}\end{array}$ & $\begin{array}{c}\text { Central } \\
\text { China, } \\
2018 \\
{[101]}\end{array}$ & $\begin{array}{l}\text { China, } \\
2018 \\
{[102]}\end{array}$ & $\begin{array}{l}\text { Iran, } \\
2020 \\
{[103]}\end{array}$ \\
\hline Antibiotic & \multicolumn{12}{|c|}{ Antibiotic Resistance } \\
\hline Ampicillin & $86.5 \%$ & $75.41 \%$ & $84.2 \%$ & $100 \%$ & $82.2 \%$ & $51.7 \%$ & $79.0 \%$ & $83 \%$ & $36.1 \%$ & $81.0 \%$ & $55.6 \%$ & $70.8 \%$ \\
\hline $\begin{array}{l}\text { Amoxicillin- } \\
\text { clavulanic } \\
\text { acid }\end{array}$ & 32.7 & $42.62 \%$ & - & - & - & $7.1 \%$ & $15 \%$ & - & $2.4 \%$ & - & $9.3 \%$ & - \\
\hline Cefuroxime & $40.4 \%$ & - & - & - & - & $23.2 \%$ & - & - & $11.1 \%$ & $61.9 \%$ & $25.8 \%$ & - \\
\hline Cefotaxime & $36.5 \%$ & $19.67 \%$ & $73.6 \%$ & $64.7 \%$ & - & - & - & $32.1 \%$ & $11.2 \%$ & $66.7 \%$ & $25.8 \%$ & $35.4 \%$ \\
\hline Cefepime & $9.6 \%$ & - & - & - & - & $3.6 \%$ & - & - & $14.3 \%$ & $38.1 \%$ & $9.3 \%$ & - \\
\hline Imipenem & $0 \%$ & - & - & $0 \%$ & - & - & - & - & $0 \%$ & $14.3 \%$ & $0 \%$ & $0 \%$ \\
\hline Meropenem & $0 \%$ & - & - & $0 \%$ & - & - & - & - & $0 \%$ & $14.3 \%$ & $0 \%$ & - \\
\hline Gentamycin & $36.5 \%$ & $21.31 \%$ & $10.5 \%$ & $11.76 \%$ & - & $5.5 \%$ & - & $13.2 \%$ & $1 \%$ & $47.6 \%$ & $37.7 \%$ & - \\
\hline Ciprofloxacin & $25.0 \%$ & $4.92 \%$ & $0 \%$ & $35.29 \%$ & - & $7.1 \%$ & $0 \%$ & $45.3 \%$ & $5 \%$ & $42.9 \%$ & $5.3 \%$ & $7.7 \%$ \\
\hline $\begin{array}{c}\text { Trimethoprim- } \\
\text { sulphamethoxazole }\end{array}$ & $63.5 \%$ & $57.38 \%$ & $73.7 \%$ & $76.47 \%$ & - & $42.9 \%$ & $79.0 \%$ & $83 \%$ & $25.9 \%$ & $66.7 \%$ & $47.7 \%$ & $56.9 \%$ \\
\hline Tetracycline & $69.2 \%$ & $78.69 \%$ & $63.2 \%$ & $35.29 \%$ & - & $46.4 \%$ & - & $94.3 \%$ & $28.6 \%$ & - & $58.9 \%$ & $46.2 \%$ \\
\hline
\end{tabular}

\section{Epidemiology}

Even if in the last decades the incidence of EPEC strains in the infectious diarrheal disease decreased, especially in developed countries, EPEC strains are still responsible for numerous cases of infantile watery diarrhea, causing sporadic cases, as well as outbreaks with significant rates of morbidity and mortality $[27,55,104]$.

There are a lot of differences between the reported prevalence for EPEC infections, coming from differences among age groups, populations, diagnostic methods, socioeconomic status, and geographic regions. The epidemiology of infectious diarrhea caused by EPEC changed in the last decades. While for many decades typical EPEC strains were strongly associated with diarrhea in children under 1 year old (especially under 6 months) $[1,25,27,105]$, more recent studies failed to identify the same strong association. In Brazil, in a study conducted between 1998-1999, 38\% of the EPEC strains were atypical, while between 2001-2002, 92\% were atypical $[11,90,106]$. Typical EPEC strains are still the most frequently identified in the diarrhea etiology in some less developed areas (Asian, African regions) [107-112].

Transmission and Reservoir

The transmission of EPEC is through oral-fecal route, contaminated fluids, surfaces, and an important source of infection is asymptomatic carriers [24]. For the typical EPEC strains, humans (symptomatic/asymptomatic) are the major known reservoir. These strains are rarely isolated from animals, while the atypical ones are frequent isolated from animals $[24,71,77,113-115]$.

Vaccine

No vaccines are currently available to prevent EPEC infections, but this is a major research concern in present times $[116,117]$. EspB is the most important protein considered for EPEC vaccine development, because of its major involvement in the pathogenesis. The vaccine development is difficult because three variants of the EspB protein $(\alpha, \beta, \gamma)$ exist [116]. A hybrid recombinant protein (combining the three variants) was proposed as an antigen that could be used in vaccines, to generate the production of antibodies [117]. 
A synthetic peptide was also described, by binding to EspB it was able to reduce, in vitro, the adherence of EPEC to cells up to $40 \%$. Other vaccine candidates use the translocator protein EspA as a target. These peptide-based strategies could be effective, but their usage against the LEE-positive strains would be limited [116].

Author Contributions: Conceptualization, A.D.M., A.M., C.N.C., F.T.; methodology, A.D.M., A.M., C.N.C., F.T., B.T., V.M., L.D.; software, A.D.M., A.M., C.N.C.; validation, A.D.M., A.M., C.N.C., F.T., B.T., V.M., L.D.; formal analysis, A.D.M., A.M., C.N.C., F.T., B.T., V.M., L.D.; investigation, A.D.M., A.M., C.N.C., F.T., B.T., V.M., L.D.; resources, A.D.M., A.M., C.N.C., F.T., B.T., V.M., L.D.; data curation, A.D.M., A.M., C.N.C., F.T.; writing—original draft preparation, A.D.M., A.M., C.N.C., F.T., B.T., V.M., L.D.; writing-review and editing, A.D.M., A.M., C.N.C., F.T.; visualization, A.D.M., A.M., C.N.C., F.T.; supervision, A.D.M., A.M., C.N.C., F.T.; project administration, A.D.M.; funding acquisition, A.D.M. All authors have read and agreed to the published version of the manuscript.

Funding: This research was funded by the AMLR (Romanian Association of Laboratory Medicine) Research Grant number 9103/23.07.2019.

Institutional Review Board Statement: Not applicable.

Informed Consent Statement: Not applicable.

Data Availability Statement: Data sharing not applicable.

Acknowledgments: The authors would like to thank to Diana Liliana Mare for the graphic design.

Conflicts of Interest: The authors declare no conflict of interest.

\section{References}

1. Troeger, C.; Blacker, B.F.; Khalil, I.A.; Rao, P.C.; Cao, S.; Zimsen, S.R.; Albertson, S.B.; Stanaway, J.D.; Deshpande, A.; Abebe, Z.; et al. Estimates of the Global, Regional, and National Morbidity, Mortality, and Aetiologies of Diarrhoea in 195 Countries: A Systematic Analysis for the Global Burden of Disease Study 2016. Lancet Infect. Dis. 2018, 18, 1211-1228. [CrossRef]

2. Yu, J.; Jing, H.; Lai, S.; Xu, W.; Li, M.; Wu, J.; Liu, W.; Yuan, Z.; Chen, Y.; Zhao, S.; et al. Etiology of Diarrhea among Children under the Age Five in China: Results from a Five-Year Surveillance. J. Infect. 2015, 71, 19-27. [CrossRef] [PubMed]

3. Hazen, T.H.; Donnenberg, M.S.; Panchalingam, S.; Antonio, M.; Hossain, A.; Mandomando, I.; Ochieng, J.B.; Ramamurthy, T.; Tamboura, B.; Qureshi, S.; et al. Genomic Diversity of EPEC Associated with Clinical Presentations of Differing Severity. Nat. Microbiol. 2016, 1, 15014. [CrossRef] [PubMed]

4. Radlović, N.; Leković, Z.; Vuletić, B.; Radlović, V.; Simić, D. Acute Diarrhea in Children. Srp. Arh. Celok. Lek. 2015, 143, 755-762. [CrossRef]

5. Bellido-Blasco, J.B.; Arnedo-Pena, A. Epidemiology of Infectious Diarrhea. Encycl. Environ. Health 2011, 659-671. [CrossRef]

6. Allocati, N.; Masulli, M.; Alexeyev, M.F.; Di Ilio, C. Escherichia coli in Europe: An Overview. Int. J. Environ. Res. Public Health 2013, 10, 6235-6254. [CrossRef]

7. Kotloff, K.L. The Burden and Etiology of Diarrheal Illness in Developing Countries. Pediatric Clin. N. Am. 2017, 64, $799-814$. [CrossRef]

8. Robins-Browne, R.M.; Hartland, E.L. Escherichia coli as a Cause of Diarrhea. J. Gastroenterol. Hepatol. 2002, 17, 467-475. [CrossRef]

9. Escherich, T. The Intestinal Bacteria of the Neonate and Breast-Fed Infant. 1884. Rev. Infect. Dis. 1988, 10, 1220-1225. [CrossRef]

10. Chaudhuri, R.R.; Henderson, I.R. The Evolution of the Escherichia coli Phylogeny. Infect. Genet. Evol. 2012, 12, 214-226. [CrossRef]

11. Gomes, T.A.T.; Elias, W.P.; Scaletsky, I.C.A.; Guth, B.E.C.; Rodrigues, J.F.; Piazza, R.M.F.; Ferreira, L.C.S.; Martinez, M.B. Diarrheagenic Escherichia coli. Braz. J. Microbiol. 2016, 47, 3-30. [CrossRef] [PubMed]

12. Fratamico, P.M.; DebRoy, C.; Liu, Y.; Needleman, D.S.; Baranzoni, G.M.; Feng, P. Advances in Molecular Serotyping and Subtyping of Escherichia coli. Front. Microbiol. 2016, 7. [CrossRef] [PubMed]

13. DebRoy, C.; Fratamico, P.M.; Roberts, E. Molecular Serogrouping of Escherichia coli. Anim. Health Res. Rev. 2018, 1-16. [CrossRef] [PubMed]

14. Campos, L.C.; Franzolin, M.R.; Trabulsi, L.R. Diarrheagenic Escherichia coli Categories among the Traditional Enteropathogenic E. coli O Serogroups: A Review. Memórias Do Inst. Oswaldo Cruz 2004, 99, 545-552. [CrossRef] [PubMed]

15. Díaz-Jiménez, D.; García-Meniño, I.; Herrera, A.; García, V.; López-Beceiro, A.M.; Alonso, M.P.; Blanco, J.; Mora, A. Genomic Characterization of Escherichia coli Isolates Belonging to a New Hybrid AEPEC/ExPEC Pathotype O153:H10-A-ST10 Eae-Beta1 Occurred in Meat, Poultry, Wildlife and Human Diarrheagenic Samples. Antibiotics 2020, 9, 192. [CrossRef]

16. Abdalhamid, B.; Mccutchen, E.L.; Bouska, A.C.; Weiwei, Z.; Loeck, B.; Hinrichs, S.H.; Iwen, P.C. Whole Genome Sequencing to Characterize Shiga Toxin-Producing Escherichia coli O26 in a Public Health Setting. J. Infect. Public Health 2019, 12, 884-889. [CrossRef] [PubMed] 
17. Robins-Browne, R.M.; Holt, K.E.; Ingle, D.J.; Hocking, D.M.; Yang, J.; Tauschek, M. Are Escherichia coli Pathotypes Still Relevant in the Era of Whole-Genome Sequencing? Front. Cell Infect. Microbiol. 2016, 6. [CrossRef]

18. Koutsoumanis, K.; Allende, A.; Alvarez-Ordóñez, A.; Bolton, D.; Bover-Cid, S.; Chemaly, M.; Davies, R.; Cesare, A.D.; Hilbert, F.; Lindqvist, R.; et al. Whole Genome Sequencing and Metagenomics for Outbreak Investigation, Source Attribution and Risk Assessment of Food-Borne Microorganisms. EFSA J. 2019, 17, e05898. [PubMed]

19. Arimizu, Y.; Kirino, Y.; Sato, M.P.; Uno, K.; Sato, T.; Gotoh, Y.; Auvray, F.; Brugere, H.; Oswald, E.; Mainil, J.G.; et al. Large-Scale Genome Analysis of Bovine Commensal Escherichia coli Reveals That Bovine-Adapted E. coli Lineages Are Serving as Evolutionary Sources of the Emergence of Human Intestinal Pathogenic Strains. Genome Res. 2019, 29, 1495-1505. [CrossRef]

20. Iguchi, A.; Thomson, N.R.; Ogura, Y.; Saunders, D.; Ooka, T.; Henderson, I.R.; Harris, D.; Asadulghani, M.; Kurokawa, K.; Dean, P.; et al. Complete Genome Sequence and Comparative Genome Analysis of Enteropathogenic Escherichia coli O127:H6 Strain E2348/69. J. Bacteriol. 2009, 191, 347-354. [CrossRef]

21. Kaper, J.B. Pathogenic Escherichia coli. Int. J. Med. Microbiol. 2005, 295, 355-356. [CrossRef] [PubMed]

22. Chervy, M.; Barnich, N.; Denizot, J. Adherent-Invasive E. coli: Update on the Lifestyle of a Troublemaker in Crohn's Disease. Int. J. Mol. Sci. 2020, 21, 3734. [CrossRef] [PubMed]

23. Meza-Segura, M.; Estrada-Garcia, T. Diffusely Adherent Escherichia coli. In Escherichia coli in the Americas; Torres, A.G., Ed.; Springer International Publishing: Cham, Switzerland, 2016; pp. 125-147; ISBN 978-3-319-45092-6.

24. Croxen, M.A.; Law, R.J.; Scholz, R.; Keeney, K.M.; Wlodarska, M.; Finlay, B.B. Recent Advances in Understanding Enteric Pathogenic Escherichia coli. Clin. Microbiol. Rev. 2013, 26, 822-880. [CrossRef] [PubMed]

25. Nataro, J.P.; Kaper, J.B. Diarrheagenic Escherichia coli. Clin. Microbiol. Rev. 1998, 11, 142-201. [CrossRef] [PubMed]

26. Hu, J.; Torres, A.G. Enteropathogenic Escherichia coli: Foe or Innocent Bystander? Clin Microbiol. Infect. 2015, 21, 729-734. [CrossRef] [PubMed]

27. Trabulsi, L.R.; Keller, R.; Gomes, T.A.T. Typical and Atypical Enteropathogenic Escherichia coli. Emerg. Infect. Dis. J. Cdc 2002, 8 . [CrossRef]

28. Sánchez, S.; Llorente, M.T.; Echeita, M.A.; Herrera-León, S. Development of Three Multiplex PCR Assays Targeting the 21 Most Clinically Relevant Serogroups Associated with Shiga Toxin-Producing E. coli Infection in Humans. PLoS ONE 2015, 10. [CrossRef]

29. Joensen, K.G.; Tetzschner, A.M.M.; Iguchi, A.; Aarestrup, F.M.; Scheutz, F. Rapid and Easy In Silico Serotyping of Escherichia coli Isolates by Use of Whole-Genome Sequencing Data. J. Clin. Microbiol. 2015, 53, 2410-2426. [CrossRef]

30. Scaletsky, I.C.; Silva, M.L.; Toledo, M.R.; Davis, B.R.; Blake, P.A.; Trabulsi, L.R. Correlation between Adherence to HeLa Cells and Serogroups, Serotypes, and Bioserotypes of Escherichia coli. Infect. Immun. 1985, 49, 528-532. [CrossRef]

31. Ochoa, T.J.; Contreras, C.A. Enteropathogenic E. coli (EPEC) Infection in Children. Curr. Opin. Infect. Dis. 2011, 24, 478. [CrossRef]

32. Singh, A.P.; Aijaz, S. Enteropathogenic E. coli: Breaking the Intestinal Tight Junction Barrier. F1000Res 2016, 4, 231. [CrossRef]

33. Cepeda-Molero, M.; Berger, C.N.; Walsham, A.D.S.; Ellis, S.J.; Wemyss-Holden, S.; Schüller, S.; Frankel, G.; Fernández, L.Á. Attaching and Effacing (A/E) Lesion Formation by Enteropathogenic E. coli on Human Intestinal Mucosa Is Dependent on Non-LEE Effectors. PLoS Pathog. 2017, 13, e1006706. [CrossRef] [PubMed]

34. De Jong, M.F.; Alto, N.M. Cooperative Immune Suppression by Escherichia coli and Shigella Effector Proteins. Infect. Immun. 2018, 86. [CrossRef] [PubMed]

35. Montso, P.K.; Mlambo, V.; Ateba, C.N. The First Isolation and Molecular Characterization of Shiga Toxin-Producing Virulent Multi-Drug Resistant Atypical Enteropathogenic Escherichia coli O177 Serogroup From South African Cattle. Front. Cell. Infect. Microbiol. 2019, 9. [CrossRef]

36. Dean, P.; Kenny, B. The Effector Repertoire of Enteropathogenic E. coli: Ganging up on the Host Cell. Curr. Opin. Microbiol. 2009, 12, 101-109. [CrossRef]

37. Litvak, Y.; Sharon, S.; Hyams, M.; Zhang, L.; Kobi, S.; Katsowich, N.; Dishon, S.; Nussbaum, G.; Dong, N.; Shao, F.; et al. Epithelial Cells Detect Functional Type III Secretion System of Enteropathogenic Escherichia coli through a Novel NF-KB Signaling Pathway. PLoS Pathog. 2017, 13, e1006472. [CrossRef] [PubMed]

38. Pinaud, L.; Sansonetti, P.J.; Phalipon, A. Host Cell Targeting by Enteropathogenic Bacteria T3SS Effectors. Trends Microbiol. 2018, 26, 266-283. [CrossRef]

39. Leh, H.; Khodr, A.; Bouger, M.-C.; Sclavi, B.; Rimsky, S.; Bury-Moné, S. Bacterial-Chromatin Structural Proteins Regulate the Bimodal Expression of the Locus of Enterocyte Effacement (LEE) Pathogenicity Island in Enteropathogenic Escherichia coli. mBio 2017, 8. [CrossRef]

40. Pal, R.R.; Baidya, A.K.; Mamou, G.; Bhattacharya, S.; Socol, Y.; Kobi, S.; Katsowich, N.; Ben-Yehuda, S.; Rosenshine, I. Pathogenic E. coli Extracts Nutrients from Infected Host Cells Utilizing Injectisome Components. Cell 2019, 177, 683-696.e18. [CrossRef]

41. Navarro-Garcia, F.; Serapio-Palacios, A.; Ugalde-Silva, P.; Tapia-Pastrana, G.; Chavez-Dueñas, L. Actin Cytoskeleton Manipulation by Effector Proteins Secreted by Diarrheagenic Escherichia coli Pathotypes. Available online: https://www.hindawi.com/journals/ bmri/2013/374395/ (accessed on 27 December 2020).

42. Guignot, J.; Segura, A.; Tran Van Nhieu, G. The Serine Protease EspC from Enteropathogenic Escherichia coli Regulates Pore Formation and Cytotoxicity Mediated by the Type III Secretion System. PLoS Pathog. 2015, 11, e1005013. [CrossRef]

43. Clarke, S.C.; Haigh, R.D.; Freestone, P.P.E.; Williams, P.H. Virulence of Enteropathogenic Escherichia coli, a Global Pathogen. Clin. Microbiol. Rev. 2003, 16, 365-378. [CrossRef] [PubMed] 
44. Vallance, B.A.; Finlay, B.B. Exploitation of Host Cells by Enteropathogenic Escherichia coli. Proc. Natl. Acad. Sci. USA 2000, 97, 8799-8806. [CrossRef] [PubMed]

45. Franzin, F.M.; Sircili, M.P. Locus of Enterocyte Effacement: A Pathogenicity Island Involved in the Virulence of Enteropathogenic and Enterohemorragic Escherichia coli Subjected to a Complex Network of Gene Regulation. Biomed. Res. Int. 2015, 2015. [CrossRef] [PubMed]

46. Donnenberg, M.S.; Kaper, J.B. Enteropathogenic Escherichia coli. Infect. Immun. 1992, 60, 3953-3961. [CrossRef] [PubMed]

47. Scholz, R.; Imami, K.; Scott, N.E.; Trimble, W.S.; Foster, L.J.; Finlay, B.B. Novel Host Proteins and Signaling Pathways in Enteropathogenic E. coli Pathogenesis Identified by Global Phosphoproteome Analysis. Mol. Cell. Proteom. 2015, 14, 1927-1945. [CrossRef] [PubMed]

48. Hartland, E.L.; Leong, J. Enteropathogenic and Enterohemorrhagic E. coli: Ecology, Pathogenesis, and Evolution. Front. Cell. Infect. Microbiol. 2013, 3. [CrossRef] [PubMed]

49. Shenoy, A.R.; Furniss, R.C.D.; Goddard, P.J.; Clements, A. Modulation of Host Cell Processes by T3SS Effectors. Curr. Top. Microbiol. Immunol. 2018, 416, 73-115. [CrossRef]

50. Song, T.; Li, K.; Zhou, W.; Zhou, J.; Jin, Y.; Dai, H.; Xu, T.; Hu, M.; Ren, H.; Yue, J.; et al. A Type III Effector NleF from EHEC Inhibits Epithelial Inflammatory Cell Death by Targeting Caspase-4. Biomed. Res. Int. 2017, 2017. [CrossRef] [PubMed]

51. Pearson, J.S.; Giogha, C.; Ong, S.Y.; Kennedy, C.L.; Kelly, M.; Robinson, K.S.; Wong, T.; Mansell, A.; Riedmaier, P.; Oates, C.V.; et al. A Type III Effector Antagonises Death Receptor Signalling during Bacterial Gut Infection. Nature 2013, 501, 247-251. [CrossRef]

52. Wong, A.R.C.; Pearson, J.S.; Bright, M.D.; Munera, D.; Robinson, K.S.; Lee, S.F.; Frankel, G.; Hartland, E.L. Enteropathogenic and Enterohaemorrhagic Escherichia coli: Even More Subversive Elements. Mol. Microbiol. 2011, 80, 1420-1438. [CrossRef]

53. Ugalde-Silva, P.; Gonzalez-Lugo, O.; Navarro-Garcia, F. Tight Junction Disruption Induced by Type 3 Secretion System Effectors Injected by Enteropathogenic and Enterohemorrhagic Escherichia coli. Front. Cell Infect. Microbiol. 2016, 6. [CrossRef] [PubMed]

54. Creuzburg, K.; Giogha, C.; Wong Fok Lung, T.; Scott, N.E.; Mühlen, S.; Hartland, E.L.; Pearson, J.S. The Type III Effector NleD from Enteropathogenic Escherichia coli Differentiates between Host Substrates P38 and JNK. Infect. Immun. 2017, 85. [CrossRef] [PubMed]

55. Deborah Chen, H.; Frankel, G. Enteropathogenic Escherichia coli: Unravelling Pathogenesis. FEMS Microbiol. Rev. 2005, 29, 83-98 [CrossRef] [PubMed]

56. Serapio-Palacios, A.; Navarro-Garcia, F. EspC, an Autotransporter Protein Secreted by Enteropathogenic Escherichia coli, Causes Apoptosis and Necrosis through Caspase and Calpain Activation, Including Direct Procaspase-3 Cleavage. mBio $2016,7$. [CrossRef] [PubMed]

57. Sanchez-Villamil, J.I.; Navarro-Garcia, F.; Castillo-Romero, A.; Gutierrez-Gutierrez, F.; Tapia, D.; Tapia-Pastrana, G. Curcumin Blocks Cytotoxicity of Enteroaggregative and Enteropathogenic Escherichia coli by Blocking Pet and EspC Proteolytic Release From Bacterial Outer Membrane. Front. Cell Infect. Microbiol. 2019, 9. [CrossRef]

58. Habouria, H.; Pokharel, P.; Maris, S.; Garénaux, A.; Bessaiah, H.; Houle, S.; Veyrier, F.J.; Guyomard-Rabenirina, S.; Talarmin A.; Dozois, C.M. Three New Serine-Protease Autotransporters of Enterobacteriaceae (SPATEs) from Extra-Intestinal Pathogenic Escherichia coli and Combined Role of SPATEs for Cytotoxicity and Colonization of the Mouse Kidney. Virulence 2019, 10, 568-587. [CrossRef]

59. Navarro-Garcia, F.; Serapio-Palacios, A.; Vidal, J.E.; Salazar, M.I.; Tapia-Pastrana, G. EspC Promotes Epithelial Cell Detachment by Enteropathogenic Escherichia coli via Sequential Cleavages of a Cytoskeletal Protein and Then Focal Adhesion Proteins. Infect. Immun. 2014, 82, 2255-2265. [CrossRef]

60. Govindarajan, D.K.; Viswalingam, N.; Meganathan, Y.; Kandaswamy, K. Adherence Patterns of Escherichia coli in the Intestine and Its Role in Pathogenesis. Med. Microecol. 2020, 5, 100025. [CrossRef]

61. Xicohtencatl-Cortes, J.; Saldaña, Z.; Deng, W.; Castañeda, E.; Freer, E.; Tarr, P.I.; Finlay, B.B.; Puente, J.L.; Girón, J.A. Bacterial Macroscopic Rope-like Fibers with Cytopathic and Adhesive Properties. J. Biol. Chem. 2010, 285, 32336-32342. [CrossRef]

62. Kaper, J.B.; Nataro, J.P.; Mobley, H.L.T. Pathogenic Escherichia coli. Nat. Rev. Microbiol. 2004, 2, 123-140. [CrossRef]

63. Lapointe, T.K.; O'Connor, P.M.; Buret, A.G. The Role of Epithelial Malfunction in the Pathogenesis of Enteropathogenic E. coli -Induced Diarrhea. Lab. Investig. 2009, 89, 964-970. [CrossRef] [PubMed]

64. Gujral, T.; Kumar, A.; Priyamvada, S.; Saksena, S.; Gill, R.K.; Hodges, K.; Alrefai, W.A.; Hecht, G.A.; Dudeja, P.K. Mechanisms of DRA Recycling in Intestinal Epithelial Cells: Effect of Enteropathogenic E. coli. Am. J. Physiol. Cell Physiol. 2015, 309, C835-C846. [CrossRef] [PubMed]

65. Cao, L.; Yuan, Z.; Liu, M.; Stock, C. (Patho-)Physiology of Na+/H+ Exchangers (NHEs) in the Digestive System. Front. Physiol. 2020, 10. [CrossRef] [PubMed]

66. Gurney, M.A.; Laubitz, D.; Ghishan, F.K.; Kiela, P.R. Pathophysiology of Intestinal Na+/H+ Exchange. Cell Mol. Gastroenterol. Hepatol. 2016, 3, 27-40. [CrossRef]

67. Das, S.; Jayaratne, R.; Barrett, K.E. The Role of Ion Transporters in the Pathophysiology of Infectious Diarrhea. Cell Mol. Gastroenterol. Hepatol. 2018, 6, 33-45. [CrossRef]

68. Anand, S.; Mandal, S.; Patil, P.; Tomar, S.K. Pathogen-Induced Secretory Diarrhea and Its Prevention. Eur. J. Clin. Microbiol. Infect. Dis. 2016, 35, 1721-1739. [CrossRef]

69. Broz, P.; Dixit, V.M. Inflammasomes: Mechanism of Assembly, Regulation and Signalling. Nat. Rev. Immunol. 2016, 16, 407-420. [CrossRef] 
70. Nguyen, R.N.; Taylor, L.S.; Tauschek, M.; Robins-Browne, R.M. Atypical Enteropathogenic Escherichia coli Infection and Prolonged Diarrhea in Children. Emerg. Infect. Dis. 2006, 12, 597-603. [CrossRef]

71. Ronin, I.; Katsowich, N.; Rosenshine, I.; Balaban, N.Q. A Long-Term Epigenetic Memory Switch Controls Bacterial Virulence Bimodality. eLife 2017, 6, e19599. [CrossRef]

72. Nair, G.B.; Ramamurthy, T.; Bhattacharya, M.K.; Krishnan, T.; Ganguly, S.; Saha, D.R.; Rajendran, K.; Manna, B.; Ghosh, M.; Okamoto, K.; et al. Emerging Trends in the Etiology of Enteric Pathogens as Evidenced from an Active Surveillance of Hospitalized Diarrhoeal Patients in Kolkata, India. Gut Pathog. 2010, 2, 4. [CrossRef]

73. Okeke, I.N. Diarrheagenic Escherichia coli in Sub-Saharan Africa: Status, Uncertainties and Necessities. J. Infect. Dev. Ctries. 2009, 3, 817-842. [CrossRef] [PubMed]

74. Spina, A.; Kerr, K.G.; Cormican, M.; Barbut, F.; Eigentler, A.; Zerva, L.; Tassios, P.; Popescu, G.A.; Rafila, A.; Eerola, E.; et al. Spectrum of Enteropathogens Detected by the FilmArray GI Panel in a Multicentre Study of Community-Acquired Gastroenteritis. Clin. Microbiol. Infect. 2015, 21, 719-728. [CrossRef] [PubMed]

75. Enserink, R.; Scholts, R.; Bruijning-Verhagen, P.; Duizer, E.; Vennema, H.; de Boer, R.; Kortbeek, T.; Roelfsema, J.; Smit, H.; Kooistra-Smid, M.; et al. High Detection Rates of Enteropathogens in Asymptomatic Children Attending Day Care. PLoS ONE 2014, 9, e89496. [CrossRef] [PubMed]

76. Estrada-Garcia, T.; Lopez-Saucedo, C.; Thompson-Bonilla, R.; Abonce, M.; Lopez-Hernandez, D.; Santos, J.I.; Rosado, J.L.; DuPont, H.L.; Long, K.Z. Association of Diarrheagenic Escherichia coli Pathotypes with Infection and Diarrhea among Mexican Children and Association of Atypical Enteropathogenic E. coli with Acute Diarrhea. J. Clin. Microbiol. 2009, 47, 93-98. [CrossRef]

77. Hernandes, R.T.; Elias, W.P.; Vieira, M.A.M.; Gomes, T.A.T. An Overview of Atypical Enteropathogenic Escherichia coli. Fems Microbiol. Lett. 2009, 297, 137-149. [CrossRef]

78. Girón, J.A.; Qadri, F.; Azim, T.; Jarvis, K.J.; Kaper, J.B.; Albert, M.J. Monoclonal Antibodies Specific for the Bundle-Forming Pilus of Enteropathogenic Escherichia coli. Infect. Immun. 1995, 63, 4949-4952. [CrossRef]

79. Gismero-Ordoñez, J.; Dall'Agnol, M.; Trabulsi, L.R.; Girón, J.A. Expression of the Bundle-Forming Pilus by Enteropathogenic Escherichia coli Strains of Heterologous Serotypes. J. Clin. Microbiol. 2002, 40, 2291-2296. [CrossRef]

80. Nakasone, N.; Toma, C.; Lu, Y.; Iwanaga, M. Development of a Rapid Immunochromatographic Test to Identify Enteropathogenic and Enterohemorrhagic Escherichia coli by Detecting EspB. Diagn. Microbiol. Infect. Dis. 2007, 57, 21-25. [CrossRef]

81. Lu, Y.; Toma, C.; Honma, Y.; Iwanaga, M. Detection of EspB Using Reversed Passive Latex Agglutination: Application to Determination of Enteropathogenic Escherichia coli. Diagn. Microbiol. Infect. Dis. 2002, 43, 7-12. [CrossRef]

82. Rocha, L.B.; Santos, A.R.R.; Munhoz, D.D.; Cardoso, L.T.A.; Luz, D.E.; Andrade, F.B.; Horton, D.S.P.Q.; Elias, W.P.; Piazza, R.M.F. Development of a Rapid Agglutination Latex Test for Diagnosis of Enteropathogenic and Enterohemorrhagic Escherichia coli Infection in Developing World: Defining the Biomarker, Antibody and Method. PLoS Negl. Trop. Dis. 2014, 8, e3150. [CrossRef]

83. Ashworth, M.; White, P.; Jongsma, H.; Schofield, P.; Armstrong, D. Antibiotic Prescribing and Patient Satisfaction in Primary Care in England: Cross-Sectional Analysis of National Patient Survey Data and Prescribing Data. Br. J. Gen. Pr. 2016, 66, e40-e46. [CrossRef] [PubMed]

84. Bruzzese, E.; Giannattasio, A.; Guarino, A. Antibiotic Treatment of Acute Gastroenteritis in Children. F1000Research 2018, 7. [CrossRef] [PubMed]

85. Zollner-Schwetz, I.; Krause, R. Therapy of Acute Gastroenteritis: Role of Antibiotics. Clin. Microbiol. Infect. 2015, 21, 744-749. [CrossRef] [PubMed]

86. Salam, M.; Lindberg, G.; Dite, P.; Khalif, I.; Salazar-Lindo, E.; Ramakrishna, B.S.; Goh, K.; Thomson, A.; Khan, A.G.; Krabshuis, D.J.; et al. Acute Diarrhea in Adults and Children: A Global Perspective. J. Clin. Gastroenterol. 2013, 47, 12-20.

87. Lee, T.-H.; Wong, J.G.; Lye, D.C.; Chen, M.I.; Loh, V.W.; Leo, Y.-S.; Lee, L.K.; Chow, A.L. Medical and Psychosocial Factors Associated with Antibiotic Prescribing in Primary Care: Survey Questionnaire and Factor Analysis. Br. J. Gen. Pr. 2017, 67, e168-e177. [CrossRef]

88. Subramanian, K.; Selvakkumar, C.; Vinaykumar, K.S.; Goswami, N.; Meenakshisundaram, S.; Balakrishnan, A.; Lakshmi, B.S. Tackling Multiple Antibiotic Resistance in Enteropathogenic Escherichia coli (EPEC) Clinical Isolates: A Diarylheptanoid from Alpinia Officinarum Shows Promising Antibacterial and Immunomodulatory Activity against EPEC and Its LipopolysaccharideInduced Inflammation. Int. J. Antimicrob. Agents 2009, 33, 244-250. [CrossRef]

89. Taghadosi, R.; Shakibaie, M.R.; Hosseini -Nave, H. Antibiotic Resistance, ESBL Genes, Integrons, Phylogenetic Groups and MLVA Profiles of Escherichia coli Pathotypes Isolated from Patients with Diarrhea and Farm Animals in South-East of Iran. Comp. Immunol. Microbiol. Infect. Dis. 2019, 63, 117-126. [CrossRef]

90. Scaletsky, I.C.; Souza, T.B.; Aranda, K.R.; Okeke, I.N. Genetic Elements Associated with Antimicrobial Resistance in Enteropathogenic Escherichia coli (EPEC) from Brazil. BMC Microbiol. 2010, 10, 25. [CrossRef]

91. Khairy, R.M.M.; Fathy, Z.A.; Mahrous, D.M.; Mohamed, E.S.; Abdelrahim, S.S. Prevalence, Phylogeny, and Antimicrobial Resistance of Escherichia coli Pathotypes Isolated from Children Less than 5 Years Old with Community Acquired- Diarrhea in Upper Egypt. BMC Infect Dis. 2020, 20, 908. [CrossRef]

92. Chen, Y.; Chen, X.; Zheng, S.; Yu, F.; Kong, H.; Yang, Q.; Cui, D.; Chen, N.; Lou, B.; Li, X.; et al. Serotypes, Genotypes and Antimicrobial Resistance Patterns of Human Diarrhoeagenic Escherichia coli Isolates Circulating in Southeastern China. Clin. Microbiol. Infect. 2014, 20, 52-58. [CrossRef] 
93. Zhang, S.-X.; Zhou, Y.-M.; Tian, L.-G.; Chen, J.-X.; Tinoco-Torres, R.; Serrano, E.; Li, S.-Z.; Chen, S.-H.; Ai, L.; Chen, J.-H.; et al. Antibiotic Resistance and Molecular Characterization of Diarrheagenic Escherichia coli and Non-Typhoidal Salmonella Strains Isolated from Infections in Southwest China. Infect. Dis. Poverty 2018, 7. [CrossRef] [PubMed]

94. Alikhani, M.Y.; Hashemi, S.H.; Aslani, M.M.; Farajnia, S. Prevalence and Antibiotic Resistance Patterns of Diarrheagenic Escherichia coli Isolated from Adolescents and Adults in Hamedan, Western Iran. Iran J. Microbiol. 2013, 5, 42-47.

95. Sirous, M.; Hashemzadeh, M.; Keshtvarz, M.; Amin, M.; Shams, N.; Dastoorpoor, M.; Shahin, M.; Koraei, D. Molecular Characterization and Antimicrobial Resistance of Enteropathogenic Escherichia coli in Children from Ahvaz, Iran. Available online: https: / / sites.kowsarpub.com/jjm/articles/100877.html\#abstract (accessed on 15 January 2021).

96. Thakur, N.; Jain, S.; Changotra, H.; Shrivastava, R.; Kumar, Y.; Grover, N.; Vashistt, J. Molecular Characterization of Diarrheagenic Escherichia coli Pathotypes: Association of Virulent Genes, Serogroups, and Antibiotic Resistance among Moderate-to-severe Diarrhea Patients. J. Clin. Lab. Anal. 2018, 32. [CrossRef]

97. Eltai, N.O.; Al Thani, A.A.; Al Hadidi, S.H.; Al Ansari, K.; Yassine, H.M. Antibiotic Resistance and Virulence Patterns of Pathogenic Escherichia coli Strains Associated with Acute Gastroenteritis among Children in Qatar. BMC Microbiol. 2020, 20,54 [CrossRef] [PubMed]

98. Seidman, J.C.; Johnson, L.B.; Levens, J.; Mkocha, H.; Muñoz, B.; Silbergeld, E.K.; West, S.K.; Coles, C.L. Longitudinal Comparison of Antibiotic Resistance in Diarrheagenic and Non-Pathogenic Escherichia coli from Young Tanzanian Children. Front. Microbiol. 2016, 7. [CrossRef]

99. Canizalez-Roman, A.; Flores-Villaseñor, H.M.; Gonzalez-Nuñez, E.; Velazquez-Roman, J.; Vidal, J.E.; Muro-Amador, S.; AlapizcoCastro, G.; Díaz-Quiñonez, J.A.; León-Sicairos, N. Surveillance of Diarrheagenic Escherichia coli Strains Isolated from Diarrhea Cases from Children, Adults and Elderly at Northwest of Mexico. Front. Microbiol. 2016, 7. [CrossRef]

100. Mare, A.; Man, A.; Toma, F.; Ciurea, C.N.; Coșeriu, R.L.; Vintilă, C.; Maier, A.C. Hemolysin-Producing Strains among Diarrheagenic Escherichia coli Isolated from Children under 2 Years Old with Diarrheal Disease. Pathogens 2020, 9, 1022. [CrossRef]

101. Zhou, Y.; Zhu, X.; Hou, H.; Lu, Y.; Yu, J.; Mao, L.; Mao, L.; Sun, Z. Characteristics of Diarrheagenic Escherichia coli among Children under 5 Years of Age with Acute Diarrhea: A Hospital Based Study. BMC Infect. Dis. 2018, 18. [CrossRef]

102. Xu, Y.; Sun, H.; Bai, X.; Fu, S.; Fan, R.; Xiong, Y. Occurrence of Multidrug-Resistant and ESBL-Producing Atypical Enteropathogenic Escherichia coli in China. Gut Pathog. 2018, 10, 8. [CrossRef]

103. Jafari, E.; Mostaan, S.; Bouzari, S. Characterization of Antimicrobial Susceptibility, Extended-Spectrum $\beta$-Lactamase Genes and Phylogenetic Groups of Enteropathogenic Escherichia coli Isolated from Patients with Diarrhea. Osong Public Health Res. Perspect. 2020, 11, 327-333. [CrossRef]

104. Yang, K.; Pagaling, E.; Yan, T. Estimating the Prevalence of Potential Enteropathogenic Escherichia coli and Intimin Gene Diversity in a Human Community by Monitoring Sanitary Sewage. Appl. Environ. Microbiol. 2014, 80, 119-127. [CrossRef] [PubMed]

105. Platenkamp, A.; Mellies, J.L. Environment Controls LEE Regulation in Enteropathogenic Escherichia coli. Front. Microbiol. 2018, 9. [CrossRef] [PubMed]

106. Franzolin, M.R.; Alves, R.C.B.; Keller, R.; Gomes, T.A.T.; Beutin, L.; Barreto, M.L.; Milroy, C.; Strina, A.; Ribeiro, H.; Trabulsi, L.R. Prevalence of Diarrheagenic Escherichia coli in Children with Diarrhea in Salvador, Bahia, Brazil. Memórias Do Inst. Oswaldo Cruz 2005, 100, 359-363. [CrossRef] [PubMed]

107. Rajendran, P.; Ajjampur, S.S.R.; Chidambaram, D.; Chandrabose, G.; Thangaraj, B.; Sarkar, R.; Samuel, P.; Rajan, D.P.; Kang, G. Pathotypes of Diarrheagenic Escherichia coli in Children Attending a Tertiary Care Hospital in South India. Diagn. Microbiol. Infect. Dis. 2010, 68, 117-122. [CrossRef]

108. Kotloff, K.L.; Nataro, J.P.; Blackwelder, W.C.; Nasrin, D.; Farag, T.H.; Panchalingam, S.; Wu, Y.; Sow, S.O.; Sur, D.; Breiman, R.F.; et al. Burden and Aetiology of Diarrhoeal Disease in Infants and Young Children in Developing Countries (the Global Enteric Multicenter Study, GEMS): A Prospective, Case-Control Study. Lancet 2013, 382, 209-222. [CrossRef]

109. Santona, S.; Diaz, N.; Fiori, P.L.; Francisco, M.; Sidat, M.; Cappuccinelli, P.; Rappelli, P. Genotypic and Phenotypic Features of Enteropathogenic Escherichia coli Isolated in Industrialized and Developing Countries. J. Infect. Dev. Ctries. 2013, 7, $214-219$. [CrossRef]

110. Langendorf, C.; Hello, S.L.; Moumouni, A.; Gouali, M.; Mamaty, A.-A.; Grais, R.F.; Weill, F.-X.; Page, A.-L. Enteric Bacterial Pathogens in Children with Diarrhea in Niger: Diversity and Antimicrobial Resistance. PLoS ONE 2015, 10, e0120275. [CrossRef]

111. Odetoyin, B.W.; Hofmann, J.; Aboderin, A.O.; Okeke, I.N. Diarrhoeagenic Escherichia coli in Mother-Child Pairs in Ile-Ife, South Western Nigeria. BMC Infect. Dis. 2016, 16, 28. [CrossRef]

112. Ben Salem-Ben Nejma, I.; Hassine Zaafrane, M.; Hassine, F.; Sdiri-Loulizi, K.; Ben Said, M.; Aouni, M.; Mzoughi, R. Etiology of Acute Diarrhea in Tunisian Children with Emphasis on Diarrheagenic Escherichia coli: Prevalence and Identification of E. coli Virulence Markers. Iran J. Public Health 2014, 43, 947-960.

113. Swennes, A.G.; Buckley, E.M.; Parry, N.M.A.; Madden, C.M.; García, A.; Morgan, P.B.; Astrofsky, K.M.; Fox, J.G. Enzootic Enteropathogenic Escherichia coli Infection in Laboratory Rabbits. J. Clin. Microbiol. 2012, 50, 2353-2358. [CrossRef]

114. Sekse, C.; Sunde, M.; Lindstedt, B.-A.; Hopp, P.; Bruheim, T.; Cudjoe, K.S.; Kvitle, B.; Urdahl, A.M. Potentially Human-Pathogenic Escherichia coli O26 in Norwegian Sheep Flocks. Appl. Environ. Microbiol. 2011, 77, 4949-4958. [CrossRef] [PubMed]

115. Moura, R.A.; Sircili, M.P.; Leomil, L.; Matté, M.H.; Trabulsi, L.R.; Elias, W.P.; Irino, K.; Pestana de Castro, A.F. Clonal Relationship among Atypical Enteropathogenic Escherichia coli Strains Isolated from Different Animal Species and Humans. Appl. Environ. Microbiol 2009, 75, 7399-7408. [CrossRef] [PubMed] 
116. Rojas-Lopez, M.; Monterio, R.; Pizza, M.; Desvaux, M.; Rosini, R. Intestinal Pathogenic Escherichia coli: Insights for Vaccine Development. Front. Microbiol. 2018, 9. [CrossRef] [PubMed]

117. Caetano, B.A.; Rocha, L.B.; Carvalho, E.; Piazza, R.M.F.; Luz, D. Immunogenic Domains and Secondary Structure of Escherichia coli Recombinant Secreted Protein Escherichia coli-Secreted Protein B. Front. Immunol. 2017, 8. [CrossRef] 